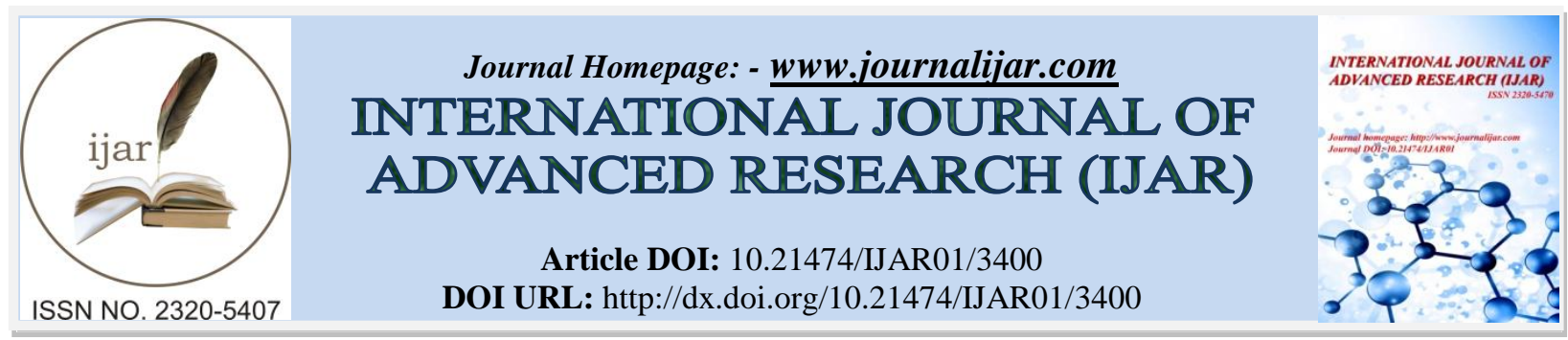

RESEARCH ARTICLE

\title{
ANALYSIS OF STOCK SPLIT AND CORPORATE FINANCIAL PERFORMANCE IN INDONESIAN STOCK EXCHANGE.
}

Dhani Ichsanuddin Nur.

Faculty of Economics and Business of UPN "Veteran" of East Java.

\section{Manuscript Info}

Manuscript History

Received: 12 December 2016

Final Accepted: 21 January 2017

Published: February 2017

Key words:-

share solution, earning per share.

\begin{abstract}
Stock split solution is one of the capital restructure forms which was executed by a company caused split effect, that is a company execution which caused the rise of stock amount which spread proportionally more than the rise of company wealth. The research purpose is to analyze finance performance and the expensive share cost in the decision of stock split. Emiten which was included sample clasified to two, namely one executed stock split in the term of Januari 2011December 2012 and one did not execute share solution in the term. The number of sample emitten is 13 emitten consited of 6 emiten which executed stock split, have net profit data, earning per share (EPS), price to book value (PBV), and price to earning ratio (PER). Analysis device was ANOVA. The research result showed that there was no significant difference finance performance between company which executed share solution and company did not execute stock split, and no significant differnece expensive share price between company which executed stock split and company which did not execute stock split.
\end{abstract}

\section{Background:-}

Competitive conditionscurrentlyrequirecompaniesto constantlydevelopthe companythroughcertain strategies. This is tosupportheimprovementofperformanceandmaintain the existence ofthe companyinthe community. One of effortstobecomethe bigger and strongercompany isthroughexpansion. The companyasan entity, generally,oriented towards achievingmaximumprofit. The right and good settingthe management ofcapitalstructurewillhelpthe course ofthe activity.Capital structurehas an important rolefor the companyboth in a critical conditionand ina healthy conditiontofinance its operations. The decision toincreaseorder crease thecapital structurecarriesdifferent consequenceson theprofit of companiesinthe future(Smith, 1990). The company's ability to achieve the maximum profit is only enabled if the company's performance is getting better. Investors or potential investors will be interested in return (rate of profit) expected for the futures relative to the risk of the company, and the benefits can compensate for the additional risk that arises (Myers, 1984). The increased performance of the company is expected to maximize the wealth of shareholders, in this case there are two approaches in describing the purpose of shareholder wealth maximization into more detailed objectives, namely through the risk-sharing approach and the liquidity-profitability approach (Hampton, 1989). Capital market,in its operation, provides the opportunity for a company that has grown well to issue securities. In this case the company will get additional funds from the public for the company's development as well as to improve the company's capital structure. The increase of financial funding sources will increase the company size, the larger the size of the company will be more and more 
alternatives the company can choose in order to optimize its performance. Large-scale enterprise has several advantages. First, the securities of large companies reflects the assets easily traded so that more liquid and have low risk (Crutchley and Hansen, 1989); second, the size of a large company happens due to the process from time to time that reflect the success of the company's performance in the past and are also useful as an indicator on the performance of the company in the future so that the relatively lower risk of bankruptcy; third, large companies have economies of scale that allow it to operate more efficiently.

\section{Matherials And Methods:-}

Stock split can be meant as splitting a sheet of stock into several sheets of shares. Stock split resulted in the increase in the number of shares outstanding without a sale and purchase transactions that change the amount of capital, the price per share is equal to $1 / \mathrm{n}$ of the price before splitting. With the stock split, the number of shares increased through a reduction in the value of shares proportionally. The main purpose of stock splits is to put stock in a more attractive trading range, which is expected to attract more buyers (Van Horne and Wachowicz, 2012). Action of stock split takes effect for investors, because they will feel as though become more prosperous due totheyhold shares in more number, so the stock split is actually an act of a company that does not have economic value (Ikenberryet. al., 1996). YulongMa et al (2000), Tawatnuntacahai and D'Mello (2002) stated that the company make a stock split was due to anticipation of a decrease in earnings volatility. Although theoretically the stock split had no economic value, but many events of stock split in the capital market gives an indication that the stock split is an important tool in the capital markets practice, which is used by management to establish a market price of shares of the company. David, O'hara, and Saar (2001), Griffin (2010), , and Tabibian (2013) stock split of the company can deliver value to the company, while investors see the stock split positively as a good investment. The announcement of a stock split is considered as a signal given by the management to the investment or potential investment that the company has performed well and has good prospects in the future (Aigbe et al, 1995, and Brealeyet. al., 2007).

Ikenberryet. al. (1996) found evidence that the stock split resulted in the re-arrangement of share price at the lower range, so the company conducts a stock split due to view that its stock price is too high. In other words, the stock price that too high is the impetus for company to conduct stock split. Hua and Ramesh (2013), Jennifer Koski (2007) said that the volatility decreases after the stock split carried out, in particular, for the lower stock price, finally there is a significant correlation between changes in the amount of change in the volatility of trading after the stock split. Vafeas(2001) stated that the stock split was preceded by their small income significantly, and has a significant relationship of incomes rise after the stock split that benefits the market participants. While Jain and Robani (2014) stated that if the company conduct stock split when economic conditions are in crisis, then the market reaction will be negative and decreased if compared to the normal economic conditions. Marwata (2001) found that the differences in financial performance and in level of expensiveness of share price measured the net income and earnings per share are not higher if compared to those of companies that do not do stock split.

\section{Variable used in this analysis are:-}

- Financial Performance

It is the financial data that the company had achieved in a certain period of time. The financial performance of ompanies that perform the stock split and the company does not do a stock split is measured by:

- Net Profit or Earnings after Tax(EAT) is an annual net profit of the period ended in December 31of year before the stock split done. The variable data is measured in rupiahs unit.

- Earning per share (EPS) is a ratio used to measure a profit level of the company. The results of the calculation of this ratio can be used to estimate the increase or decrease in the stock price of a company on the stock exchange. The EPS used is the EPS at the end of the period prior to the stock split carried out.

$$
\text { EPS }=\frac{\text { Net Profit }}{\text { Number of Shares }}
$$

- Expensiveness of stock price is the nominal price of shares traded on the capital market. Expensiveness stock price of the company conducting stock split and the company do not do a stock split is measured by:

- Price to Book Value (PBV) is a price ratio calculated by dividing the current stock price and the book value, the book value itself is a ratio calculated by dividing total net assets(asset-debt) to the total shares outstanding. PBV used is the PBV of end year before the stock split year.

$$
\text { Book Value }=\frac{\text { Total Equity (Asset-Debt) }}{\text { Number of Shares Outstanding }}
$$




$$
\mathrm{PBV}=\frac{\text { Stock Price }}{\text { Book Value }}
$$

- Price to Earnings Ratio(PER) is the ratio of the price which is calculated by dividing the current stock price by the earnings per share (EPS) is a ratio that indicate show much profit is obtained by investors or share holders of pershare. PER used is the end year PER before the stock split year.

$$
\text { PER }=\frac{\text { Stock Price }}{\text { EPS }}
$$

\section{The dependent variables:-}

Stock split is the replacement of the number of shares outstanding by the number of new shares, without changing the total nominal value. Stock split is aqualit ative variable, so in this test the variable is categorical, namely:

a. For companies that perform the stock split it will be rated 1 .

b. For companies that do notdoastocksplitit will be rated0.

\section{Sampling Method:-}

The populationstudiedwas takenfrommanufacturingcompaniesthatgo publicin Indonesian Stock Exchange. Selection ofthe sample usedisissuerslistedonthe Jakarta Stock Exchangeat 31 December 2012wereincluded in thegroupofmanufacturing industry. Issuersincluded in the samplearegroupedinto two, namelythose who conducted thestocksplitintheperiodofJanuary 2011 to December2012andthosewhodid not doa stock splitintheperiod.The number of issuerswhobecamea sample were of13issuerswhichconsists of6issuers thatdostocksplitwhichhavedataofnet profit, EPS, PBVandPERduringJanuary 2011-December 2012and7issuers thatdidnotperformthe stock split,randomlyselectedbycriteriaofissuers thathavedataofnet profit, EPS, PBVandPERduringthe study period.

\section{Data Analysis:-}

Testing was done bycomparingthevarianceand the averageofthe two groupsusingindependentsamplettest $(t$ testfortwo independent samples) which includetesttheLevenetest.To find attestortcount it can bedone by means of:

$\mathrm{H}_{0 \mathrm{Ai}}$ : Bothvariancesamples(net profit, EPS, PBV, andPER) areidentical(variance samples of companies that dostocksplitandthat do not dostocksplitis the same).

$\mathrm{H}_{1 \mathrm{Ai}}$ : Bothvariancesamples(net profit, EPS, PBV, andPER) are notidentical(variancesamples of companies that dostocksplitanddo not do thestocksplitisdifferent).

Where : if the probability $>0,05$ then $\mathrm{H}_{0 \mathrm{Ai}}$ accepted and $\mathrm{H}_{1 \mathrm{Ai}}$ rejected

If the probability $<0,05$ then $\mathrm{H}_{0 \mathrm{Ai}}$ rejectedand $\mathrm{H}_{1 \mathrm{Ai}}$ accepted

Tocarryoutthedifferent testof two averagesby $\mathrm{F}$ testis usedthe following formula:

$\mathrm{F}_{\text {count }}=\frac{\text { Mean Square Between Groups }}{\text { Mean Square Within Groups }}$

\section{Results And Discussion:-}

Test of Data Homogeneity:-

The testusedis thetestofhomogeneityofvariancethatis by Levene test, fromthe calculation results is obtainedasfollows:

Table 1:- Test of Homogeneity of Variances

\begin{tabular}{|l|l|l|l|l|}
\hline & Levene Statistic & df1 & df2 & Sig. \\
\hline Net profit (X1) & 2.590 & 1 & 18 & .125 \\
\hline EPS (X2) & 1.470 & 1 & 18 & .244 \\
\hline PBV (X3) & .245 & 1 & 18 & .627 \\
\hline PER (X4) & .206 & 1 & 18 & .655 \\
\hline
\end{tabular}

Source: Data processed

The calculation results in the table above for the financial performance which consists of net profit and earnings per share have the probability value or the significance greater than 0.05 . This means that the data of the variables of net profit and earnings per share have the uniform or equalvariances. Expensivenessofstock pricewhichconsistsofprice to book valueandprice earnings ratiohasaprobabilityorsignificancegreaterthan 0.05 , whichmeansthatthedataofthe price to bookandprice-earnings ratio variables havethesamehomogeneity. 


\section{Hypothesis Testing:-}

Hypothesis testing in this study used the different test of two averages for the samples that disjoint. The research result shows the values as presented in the table below:

Table 2:- Hypothesis Testing Results

\begin{tabular}{|l|l|l|l|l|}
\hline \multirow{2}{*}{ Variables } & \multicolumn{2}{|l|}{ Mean } & \multirow{2}{*}{ F value } & \multirow{2}{*}{$\rho$ value } \\
\cline { 2 - 3 } & Do not dostock split & Performstock splits & & 0.443 \\
\hline Net profit & 216085.21 & 69114.50 & 0.101 & 0.514 \\
\hline EPS & 74.0714 & 48.333 & 0.512 & 0.757 \\
\hline PBV & 4.3621 & 1.9350 & 0.343 & 0.565 \\
\hline PER & 23.37 & 9.225 & & \\
\hline
\end{tabular}

Source: Data processed

Based on the table 2 above, it was found that the mean of net profit of the companies that do not conduct a stock split is greater than the mean of the companies that conduct a stock split. $\mathrm{F}$ value $=0.443$ with probability ( $\rho$ value) of 0514 is for a net profit, due to the probability value greater than 0.05 then it can be stated that there is no significant difference between the net profits of companies that perform the stock split and the companies that do not perform the stock split.

The value of earnings per share of companies that do not conduct a stock split is greater than the earnings per share of companies that perform the stock split, of the calculation of $F$ value $=0.101$ with the probability ( $\rho$ value) of 0.754 , due to the probability value ( $\rho$ value) greater than 0.05 then it can be stated that there is no significant difference between the earnings per share of companies that do a stock split and companies that does not perform the stock split.

Based on the table 2 above, the mean of price to book value of the companiesthatdo not do the stock split is greater than companies that perform the stock split. From the calculation of $F$ value $=0.512$ with the probability ( $\rho$ value) of 0.483 , due to the probability value ( $\rho$ value) greater than 0.05 , it can be stated that there is no significant difference between the price to book value of companies that perform the stock split and companies that do not do stock split.

Based on the table 2 above, mean of the price earnings ratio of companies that do not conduct a stock split is greater than companies that perform the stock split. From the calculation of the $\mathrm{F}$ value it is obtained $\mathrm{F}$ value $=0.343$ with the probability ( $\rho$ value) of 0.565 , due to the probability value ( $\rho$ value) greater than 0.05 , then it can be stated that there is no significant difference between the price earnings ratio of companies that conduct a stock split and companies do not conduct stock split.

Stock split has become a tool used by management to establish the market price of company shares. Stock split is the splitting of a number of shares into more number of shares with a reduction of nominal price of per share proportionally. According to signaling theory, a stock split is an effort to give a signal about the owned information by management about the financial condition of the company, so it can be hypothesized that companies that perform the stock split had the better financial performance than companies that do not do a stock split, this meant that companies with not good condition cannot perform stock splits. The market will respond positively if the signal giver is credible, therefore, the company must demonstrate its credibility.

The first hypothesis states there is a difference in net profit after tax between companies that carry out the stock split and companies do not do a stock split. Based on the test results, this hypothesis is not verified.

The second hypothesis states that there are differences in earnings per share (EPS) between companies that carry out the stock split and companies do not do a stock split. Based on test results, this hypothesis is not verified. These results do not support the signaling theory that explains that the stock split was an effort to give a signal about the owned information by management about the financial condition of the company, so it can be hypothesized that the companies that do the stock split have better performance than companies that do not do stock split. But in this study did not be proven that the companiesthat did stock split had better financial performance than companies that did not do stock split. These results are consistent with the research conducted by Marwata (2001) which concluded that the financial performance of companies that do stock split and companies that do not do stock split is indifferent. The stock price is too high (over price) causes less active shares traded, given the stock split, the share price becomes too 
high, so that will more investors who can afford to buy the shares, the more the investors numbers would increase the liquidity of shares in the exchange.

The third hypothesis states that there is a difference of price to book value (PBV) between companies that carry out the stock split and companies do not do a stock split. Based on test results, this hypothesis is not verified.

The fourth hypothesis states that there is a difference of price earnings ratio (PER) between companies that carry out the stock split and companies do not do a stock split. Based on test results, this hypothesis is not verified. The results of this study do not support the theory of trading range hypothesis in explaining the occurrence of stock split. Theoretically, a stock split occurred due to stock prices are considered too expensive, so the stock split is an effort to drive the stock price at a specific range that is not too expensive, so it can be hypothesized that the companiesthat perform stock splitshave the price that relatively more expensive than companies that do not perform stock splits.

\section{Conclusions:-}

From the analysisand hypothesis testingabove, it can be concludedas follows:

a. For financial performance

- There is a difference in net profit between companies that carry out the stock split and companies do not do the stock split is not verified.

- There is differencein earnings of per share between companies that perform the stock split and companies that do not do a stock split is not verified.

b. Expensiveness of share prices

- There is difference of price to book value (PBV) between companies that carry out the stock split and companiesthatdo not do stock split is not verified.

- There is difference in price to earnings ratio (PER) between companies that perform stock split and companiesthatdo not do stock split is not verified.

From the analysis results and conclusions above, the the suggestions can be submitted are as follows:

1. This study does not escape from the limitations, where the period of observation only covers the period consisting of the two financial statements alone. Further research should be encouraged to further expand the observations samples or periods of financial statements, so that the research results better reflect the performance and level of stock prices expensiveness in real.

2. Some things to consider to develop this research is the need to extend the observation period of studies in several periods before the splitting is done, tests performed on various industrial objects to expand the research observations.

\section{References:-}

1. Aigbe Akhigbe, Jeff Madura, Stephen P. Zera, 1995, Long-term Valuation Effects of Stock Splits, Journal of Economics and Finance, Vol 19, Issue 3.

2. Amir, Tabibian, 2013, The Effect of Stock Split on Stock Return: Evidence from Malaysia, International Journal of Advances in Management, Technology, Engineeering Sciences, September II (12).

3. Brealey, Richarcd A., Steward C. Myers, and Alan J. Marcus, 2007, Fundamentals of Corporate Finance, $5^{\text {th }}$ Edition, McGraw-Hill Companies Inc., New York.

4. Crutchley, Claiere E., and Robert S. Hansen, 1989, A test of the Agency Theory of Managerial Ownership, Corporate Leverage, and Corporate Dividends, Journal of the Financial Management Association, Winter, pp. 34-36.

5. Easely, David, Maureen O'hara, and Gideon Saar, 2001,How Stock Splits Affect Trading: a Microstructure Appreach, The Journal of Financial and Quantitative Analysis, 36.

6. Griffin, Carroll Howard, 2010, Abnormal Return and Stock Split: The Decimalicedvs Fractional System of Stock Prices Quotes, International Journal of Business and Management, Vol 5, No. 12, December.

7. Hampton, John J., 1989, Financial Decision Making Concepts, Problem, Cashes, Fourth Edition, Prentice Hall International Inc.

8. Ikenberry, D., Rankie G., and E.K. Stice, 1996, What do Stock Splits Really Signal?,Journal of Financial and Quantitative Analysis, Vol 13, p. 357.

9. Jain, Ajeet, and Mohammad G. Robani, 2014, The Effect of Stock Split Announcement on Abnormal Return During a Financial Crisis, Journal of Finance and Accounting, Vol 14, April. 
10. Koski, Jenifer L., 2007, Does Volatility Decrease After Reverse Stock Splits, the Journal of Financial Research, Vol 30, p. 217.

11. Liu Hua, Skanthavarathar Ramesh, 2013, A Study on Stock Split Announcements and Its Impact on Stock Prices in Colombo Stock Exchange (CSE) of Srilanka, Global Journal of Management and Business, Vol 13, No6-c.

12. Marwata, 2001, KinerjaKeuangan, HargaSahamdanPemecahanSaham, JRAI, Vol 4, No. 2, Mei.

13. MuazarohdanRr.Iramani, 2005, AnalisisKinerjaKeuangan, KemahalanSahamdanLikuiditaspadaPemecahanSaham, MajalahEkonomi, Tahun XV, No. 3A, December.

14. Myers, Stewart C., 1984, The Capital Structure Puzzle, Journal of Finance, Vol 39, No. 3, pp. 575-592.

15. Smith, Clifford W., 1990, The Modern Theory of Corporate Finance, Second Edition, McGraw-Hill International Edition.

16. Tawatnuntachai, Oranee, and RanjanD’Mello, 2002, Intra-Industry Reaction to Stock Split Announcements, The Journal of Financial Research, Summer, Vol 31, p. 191.

17. Van Horne, James C., John M. Wachowicz Jr., 2012, Fundamentals of Financial Management, $13^{\text {th }}$ Edition, Prentice-Hall Inc.

18. YulongMa, Huey-Lian Sun, Jasmine Yur-Austin, 2000, Insider Trading Around Stock Split Announcements, Journal of Applied Business Research (JABR), Vol 16, No 3. 